\title{
PROFESSIONAL TRAINING OF FUTURE LOGISTICS OFFICERS AT NATIONAL MILITARY UNIVERSITY OF BULGARIA Nikolay NICHEV, Elitsa PETROVA
}

"Vassil Levski” National Military University, Veliko Tarnovo, Bulgaria, nicheff@abv.bg, elitsasd@abv.bg

\begin{abstract}
The specific of the officer's military management activities lies in its functional responsibilities. The obligations and requirements determine them. The specifics of the military management activities of logistics officer are designated by the statute of military service in the Armed Forces of the Republic of Bulgaria. This article represents the proficiency of the future logistics officers at Vasil Levski National Military University, which is achieved through training in two specialties: military training in "Organization and management of tactical units for logistics" and civil training in "Business Logistics". In the both, cadets acquire the educational and qualification degree "Bachelor".
\end{abstract}

\section{Keywords: professional training}

\section{Introduction}

The specifics of the officer's military management activities lies in its functional responsibilities. The obligations and requirements determine them. The specifics of the military management activities of logistics officer are designated by the statute of military service in the Armed Forces of the Republic of Bulgaria. [1] The proficiency of the future logistics officers at Vasil Levski National Military University is achieved through training in two specialties: military training in "Organization and management of tactical units for logistics" and civil training in "Business Logistics". In the both, cadets acquire the educational and qualification degree "Bachelor".

Besides the general duties of the commanders, the main areas of professional activity of the officer appear like:

- Development of plans for increasing preparedness for fulfilling combat tasks, mobilization and combat training
- Improving knowledge of staff and his training; planning and organizing provision activities

- Giving methodological guidance, control and assistance of the staff working with nutrition, clothing, accommodation, fire and sporting assets, building materials, fuels, lubricants and special fluids

- Development of reports, statements, plans, schedules, information and documents for logistics support

- Organization and management of keeping, accountability and participate in the verification of the status of defense products

- Preparation of requests for financial and material resources

- Organize and facilitate the holding of inventory of defense products in logistic support

- Checking personal conduct reporting, availability, quality, technical condition, and complexity in warehouses and formations of defense products 
- Organization of nutrition of the personnel

- Organization and management of production and distribution of clothing

- Organizing and leading the clothing for officers

- Organization and management of the provision of building materials for repairing of infrastructure

- Organization and management of fuel, lubricants and special liquids

- Keeping the operating report of fuels, lubricants and special fluids

- Knowing and complying with the general safety measures and those in daily activities, as well as measures for fire safety in the workplace and more. [2]

\section{Some characteristics of education of future logistics officers at "Vasil Levski" National Military University}

Education of future non-combatant officers at National Military University is achieved through the training in two specialties: military training in "Organization and management of tactical units for logistics" and civil training in "Business Logistics". In the both, cadets acquire the educational and qualification degree "Bachelor".

Preparation for management activities in civil qualification is a result of the study of five modules: "Basic subjects", "Management and Logistics" "Language training", "Physical training" and "Practical Training", which consist of 41 subjects. "Fundamentals of Management", "Resource Management", "Human Resources Management", "Strategic Management" and "Organizational Behavior" are appeared as the basic of them.

Practical training (internship) puts cadets in conditions as close to their future engagements, creating the most favorable conditions for the development of management skills. [3] It is necessary to be regarded as military management internship and as one of the most important steps for building a future logistics officers as managers. This type of learning activity allows cadets to verify and consolidate managerial knowledge and gain experience in the management of military units. When cadets perform all the duties of the officer who must manage warrior teams, his or her practical activity becomes a major factor in the formation of ability for management operations.

Besides the practical training as a separate course, cadets acquire practical skills through ongoing tactical drill exercises, tactical exercises, tactical training and learning methodology of tactical and special training.

Tactical - drill sessions is a form of initial preparation and martial assembly of troop formations. The essence of tactical drill classes is expressed in working out with cadets and class divisions of individual and to perform collective techniques in different types of warfare, first in elements and slower by repeating each element, while all cadets learn to perform them properly, and then for definite time.

Tactical exercises are designed for combat structuring actions of formations and they are one of the main forms of training in combat training of cadets. The participation of cadets in tactical exercises influence consolidation of their knowledge and build lasting habits and skills as commanders of units in performing combat tasks in various command positions.

Tactical preparation as on the field training of cadets must ensure constant combat readiness formations for conducting active work in all conditions of the situation. The tactical exercises and tactical exercises with combat shooting are notably complex and the millstone stage of troop assembly teams in the battle.

Classes in methodology of tactical and special training contribute to the development of pedagogical and methodological qualities in various subjects included in the "Training Program for Logistics Divisions of Land Forces" and create favorable conditions for the formation of managerial capabilities. [4]

The very important in preparing for 
management activities of the cadets is the performing of the functions as officials of the daily duty. The daily duty is designed to maintain military order, security and defense of the personnel and to maintain defense products of military formations, objects, polygons and bases, as well as disclosure and enforcement in higher states of readiness and performance of functional duties under specific conditions.
The daily duty include:

- To be on sentry service duty

- To be on patrol service duty

- To be on the internal service duty

- To be on implementation of operational and combat service duty. [5]

The officials of the daily duty and their relationship with the formation of managerial knowledge, skills and habits are given at the table.

Table 1: Information for the officials of the daily duty and formation of managerial knowledge, skills and habits

\begin{tabular}{|c|c|c|c|}
\hline $\begin{array}{l}\text { By } \\
\text { № }\end{array}$ & Duty Type & $\begin{array}{c}\text { Subordinate } \\
\text { Officials }\end{array}$ & $\begin{array}{c}\text { Execution of } \\
\text { functional duties }\end{array}$ \\
\hline 1. & Assistant duty in formation & $\begin{array}{c}\text { Yes } \\
\text { Officers } \\
\text { Sergeant staff } \\
\text { Soldiers }\end{array}$ & Yes \\
\hline 2. & Head of the sentry & $\begin{array}{c}\text { Yes } \\
\text { Sergeant staff } \\
\text { Soldiers }\end{array}$ & Yes \\
\hline 3. & Assistant chief of the sentry & $\begin{array}{c}\text { Yes } \\
\text { Sergeant staff } \\
\text { Soldiers }\end{array}$ & $\mathrm{N} / \mathrm{A}$ \\
\hline 4. & Attendant & $\begin{array}{c}\text { Yes } \\
\text { Sergeant staff } \\
\text { Soldiers }\end{array}$ & N/A \\
\hline 5. & 24-hour sentry & $\begin{array}{c}\text { Yes } \\
\text { Soldiers }\end{array}$ & $\mathrm{N} / \mathrm{A}$ \\
\hline 6. & Duty in park & $\begin{array}{c}\text { Yes } \\
\text { Soldiers }\end{array}$ & Yes \\
\hline 7. & Orderly in park & $\mathrm{N} / \mathrm{A}$ & $\mathrm{N} / \mathrm{A}$ \\
\hline 8. & Duty on checkpoint & $\mathrm{N} / \mathrm{A}$ & $\mathrm{N} / \mathrm{A}$ \\
\hline 9. & $\begin{array}{l}\text { Duty in battalion (battalion, } \\
\text { squadron) }\end{array}$ & $\begin{array}{c}\text { Yes } \\
\text { Officers } \\
\text { Sergeant staff } \\
\text { Soldiers } \\
\end{array}$ & Yes \\
\hline 10. & Duty in company & $\begin{array}{c}\text { Yes } \\
\text { Officers } \\
\text { Sergeant staff } \\
\end{array}$ & N/A \\
\hline 11. & Orderly in company & $\mathrm{N} / \mathrm{A}$ & $\mathrm{N} / \mathrm{A}$ \\
\hline
\end{tabular}

During their training cadets are able to perform most of the duties performed by officials of the daily detail, including practical implementation of functional duties of soldiers and sergeant staff.
The performance of the duties performed by officials of the daily duty by cadets allows gaining an idea of the overall strength of the military service, its structure and relationships between its elements and 
comparing the obtained theoretical knowledge for management activities with the implementation of specific obligations as military.

In preparation for management activities the cadets of specialty "Organization and management of tactical units for logistics" can be found two interconnected concepts for "management" and "leadership". The two concepts are often mixed. However, between terms there are important differences. Management is much more institutionalized, formal and rational act, while the leadership is more informal, unregulated and rely on emotional involvement, and can be defined as "the exaltation of the human imagination to more greater heights, striving for higher standards of performance, forming a personality beyond its normal contours." [6] At the end of their training, in accordance with the model for the construction of the social aspect of the leadership of the cadets, it is assumed that they will be members of society with highly developed civic and social culture based on formed in the training social and moral values, such as honor, duty, dignity, unselfishness, honesty, openness, heartedness, modesty, patience, perseverance, discipline, vision, selfcontrol, initiative, courage, bravery, physical agility, and other. To achieve this objective responsibility and respect have both sides in this process - the trainers and trainees. [7]

The acquisition of knowledge over the years of training occupies important role in preparing cadets for management activity.

During the first year, cadets study the disciplines: combined arms, Requirements of the statutes, Organization and use of military units and military technical equipment systems, Common tactics and basic general education courses. In the first year of training increase their combined arms training and acquire general knowledge. Therefore, a development in the preparation of management activities is relatively weakest. A key factor in development is the personality of the commanders and teachers. Under the influence of the personal example, preparation and the ability to manage and train their staff based on imitation begin to form cadets' professional training in management activities.

During the second year of training, cadets improve their theoretical and fundamental general education and start studying special military disciplines and fundamental management disciplines that provide basic knowledge for management activities. At the end of second year, cadets have acquired managerial habits as orderly and on duty in company.

During the third year of training, cadets receive a certain amount of knowledge of combined arms, military, special and fundamental (general and managerial) disciplines, they are assigned to perform certain managerial duties. In the third year, the cadets are assigned to act as commanders of a division, and so during the army service they acquire practical skills in the management of military teams. During the year, the wearing of internal service as orderly and duty in company continues and beginning the performing the duties at checkpoint.

During the fourth year of training, the cadets complete their training in civil specialty and receive interdisciplinary widespread knowledge of economics and management of material, financial, human and information resources. This year cadets continue to expand his military background, but they would be assigned the functions of deputy commander of a platoon. This year continues the wearing of internal service as orderly and duty in company and begin performing the duties of assistant-duty battalion.

At the final stage of training, in the fifth year, the dynamics in the development and improvement of management activities of cadets is greatest. This year they can improve their tactical and special preparation, occupying the post of 
commander of a platoon. The cadets acquire the abilities of qualified military specialists during the army service and have the greatest opportunities to improve practical management knowledge. The graduating cadets are highly qualified for management activity and high sense of responsibility. At the end of the military training, cadets feel themselves knowledgeable, capable and ready to offer professional and appropriate solution for a specific task.

\section{Conclusion}

Important component of the development of cadet as a manager is his professional (military, special) training. The modern concepts for solving the crisis of military and non-military character, the formation of a multi-armed structures and the increasing role of professionalism provoke demand and application of new methods and forms of vocational training in accordance with the increasing requirements of Bulgarian army and the opportunities for integration in the European defense structures.

For the formation of social skills, as a part of the management skills of the future noncombatant officer facilitate the efforts of the commanders and lecturers for achieving the objectives adopted in the Ethical Code of "Vasil Levski" National Military University. The formation of these ethical norms and values will contribute to the further socialization, personal growth and professional development of cadets to achieve the common goal - to be effective managers acting appropriately in different social situations.

\section{References}

[1] Statute for Military Service of the Armed Forces of the Republic of Bulgaria. Prom. 75/26.08.2008, amended and supplemented in SG. 38 / 18.05.2012

[2] Genev Ev., Petrova, El. Administrative model of "Vasil Levski" National Military University, Veliko Tarnovo, 2012

[3] Monev, P. Formation of the leadership skills of the cadets. IRD, S., 1975

[4] _Monev, P. Formation of the leadership skills of the cadets. IRD, S., 1975

[5] Statute for Military Service of the Armed Forces of the Republic of Bulgaria. Prom. 75/26.08.2008, amended and supplemented in SG. 38 / 18.05.2012

[6] Petrova, El. Management in a Changing World, Publishing complex of "Vasil Levski" National Military University, Veliko Tarnovo, 2012

[7] Atanasova - Krasteva, N., Leadership Establisment of Cadets, Publishing complex of "Vasil Levski" National Military University, Veliko Tarnovo, 2012 